murdered. In "Oath," the comparable address is a plea directed to God. Even within "The Elves Conceal My Buffalo and My Son," a longish narrative, there is an "aria" in which the poet calls for his missing son and on all the deities he can muster to help him find his son. "Elves" gives the reader a glimpse of another crucial aspect of U Sam Oeur's personality which helped him to survive life within a holocaust; that is humor.

Finally the poem "The Moaning Nature of Cambodia" deals with the country at this moment, and its stance is more clearly that of a citizen in exile. It addresses the fact that the country is being sold off to outside interests and it is the leaders who are doing the selling out, including Prince Sihanouk. The last stanza's mention of a "master architect" harks back to the golden age of the Angkor era, when certain architects were considered of very high rank, just below the royal family, and the implication is that such an "architect" could help re-establish a new golden age of Khmer culture, in which justice would once again be part of the system.

\title{
Bung Kriel (The Lake Where Cranes Mate)
}

\author{
for Ginny Duncan
}

The paddy fields stretch beyond the horizon.

Where water glitters, I can see palm trees dance.

Where egrets and herons flap after fishes

water buffaloes charge each other, grunting like giants.

The losers spatter water like paddle boats going upstream.

While the bull-buffalo is courting its mate

a young bull quickly mounts her-

the old bull charges and butts him away.

In the air,

the birds dive out of the sun.

Dragonflies quickly fold their wings and fall,

and grasshoppers crouch in the grass. 
Boys and girls fall into small clutchessome play reak ${ }^{1}$ and bikom, ${ }^{2}$

some sing in the trees,

others sprawl in the shade.

When the sun streaks across the horizon, the birds disperse and fly in ordered flocks to their nests and the herders lead their cattle home.

When darkness settles upon the plain insects, geckoes, and frogs rock this kingdom. A million stars drop everywhere, and farmers fall asleep in peace.

'reak: a children's game, similar to chess, which is played primarily by boys. 'bikom: another children's game, resembling jacks, played almost exclusively by girls.

\section{Oath of Allegiance (1952)}

I. Motivation

During my childhood

It was the war of liberation

The French colonialists the country was in chaos.

and the Viet Minh infiltrated. chained innocent Khmers while Khmers killed Khmers.

It was desperate-

Because I was a farm child

Often I felt miserable-
I looked at the sky, it was high.

I didn't understand anything.

I was feeling compassion for my people; they had no leaders. 